\title{
Who Reads Research Articles? An Altmetrics Analysis of Mendeley User Categories ${ }^{1}$
}

\author{
Ehsan Mohammadi ${ }^{1}$, Mike Thelwall $^{1}$, Stefanie Haustein $^{2}$, Vincent Larivière ${ }^{2,3}$ \\ E-mail: e.mohammadi@wlv.ac.uk \\ ${ }^{1}$ Statistical Cybermetrics Research Group, Faculty of Science and Engineering, University of \\ Wolverhampton, Wulfruna Street, Wolverhampton WV1 1LY, UK. \\ ${ }^{2}$ École de bibliothéconomie et des sciences de l'information, Université de Montréal, C.P. \\ 6128, Succ. Centre-Ville, Montréal, QC. H3C 3J7, Canada. \\ ${ }^{3}$ Observatoire des Sciences et des Technologies (OST), Centre Interuniversitaire de \\ Recherche sur la Science et la Technologie (CIRST), Université du Québec à Montréal, \\ CP 8888, Succ. Centre-Ville, Montréal, QC. H3C 3P8, Canada
}

\begin{abstract}
Little detailed information is known about who reads research articles and the contexts in which research articles are read. Using data about people who register in Mendeley as readers of articles, this paper explores different types of users of Clinical Medicine, Engineering and Technology, Social Science, Physics and Chemistry papers inside and outside academia. The majority of readers for all disciplines were $\mathrm{PhD}$ students, postgraduates and postdocs but other types of academics were also represented. In addition, many Clinical Medicine papers were read by medical professionals. The highest correlations between citations and Mendeley readership counts were found for types of users that often authored academic papers, except for associate professors in some subdisciplines. This suggests that Mendeley readership can reflect usage similar to traditional citation impact, if the data is restricted to readers who are also authors, without the delay of impact measured by citation counts. At the same time, Mendeley statistics can also reveal the hidden impact of some research papers, such as educational value for nonauthor users inside academia or the impact of research papers on practice for readers outside academia.
\end{abstract}

Keyword: altmetrics, Mendeley, research impact, readership analysis, social bookmarking

\footnotetext{
${ }^{1}$ This is a preprint of an article to be published in the Journal of the Association for Information Science and Technology @ copyright 2014 John Wiley \& Sons, Inc
} 


\section{Introduction}

Since the 1960s, citations have been widely used in research evaluation and monitoring. However, it is acknowledged that they alone cannot capture the full spectrum of research impact (MacRoberts \& MacRoberts, 1989; Kostoff, 1998). For example, uncited publications may still be useful (Bornmann \& Marx, in press) partly because many non-author professionals also read research articles (Price \& Gürsey, 1975; Tenopir \& King, 2000). For instance, practitioners, undergraduate students (Nicholas et al., 2005), the public (Kurtz \& Bollen, 2010) and lecturers use research publications for purposes such as teaching (Kousha \& Thelwall, 2008) or professional activities (Schloegl \& Stock, 2004), including medical practice (Bennett, Casebeer, Kristofco, \& Strasser, 2004). Therefore, it is clear that the impacts of research can go beyond knowledge advancement within science, and hence the influence of research publications in social, economic, cultural and environmental contexts needs to be identified (Bornmann, 2012; Thelwall, 2012) in research evaluation. In the same way, the Higher Education Funding Council for England (HEFCE), in the new Research Excellence Framework (REF) will consider all types of research impact outside academia (HEFCE, 2011). Therefore, multiple indicators are needed (Martin, 1996) to measure the wider influence of research publications. Measures derived from usage data have been suggested (Bollen, Van De Sompel, Hagberg, \& Chute, 2009) to capture broader research impact but due to a lack of information about users of academic publications (Bollen \& Sompel, 2008; Haustein \& Siebenlist, 2012) systematic investigations into the contexts where research papers are used have not been conducted yet.

The engagement of researchers with different social web platforms provides a novel opportunity to measure different types of research impact (Cronin, 2013a) and can help to capture many kinds of non-scientific research impact (Bornmann, in press). In particular, social web mentions of scientific publications can be retrieved from various platforms and are often grouped under the umbrella term altmetrics (Priem, Piwowar, \& Hemminger, 2012). The academic social web site Mendeley is a platform for users to manage scholarly references, create online profiles and communicate with peers. The numerous users (approx. 2.6 million in October 2013), large database, and open Applications Programming Interface (API) of Mendeley are particularly useful for compiling usage indicators. In particular, the fact that Mendeley provides the top 3 in terms of "academic status" of readers per document makes it possible to identify the users of research publications by different types of occupations and academic titles.

The first gap that this research tries to fill is to discover how diverse the readers of scholarly papers are in Mendeley. Although several studies have found correlations between Mendeley readership counts and citations (Li, Thelwall, \& Giustini, 2012; Bar-Ilan, 2012; Mohammadi $\&$ Thelwall, in press), the extent to which Mendeley readership counts actually measure readership, and in how far they capture the same or a different impact than citations is still not known. Thus, the current study aims to fill this gap by analysing the effect of academic status on the correlations between citations and Mendeley readership counts. 


\section{Literature review}

\section{Social media and scientific publications}

Informetrics is the study of any form of information with quantitative approaches (TagueSutcliffe, 1992) including bibliometrics, scientometrics and citation analysis (Egghe \& Rousseau, 1990). Cybermetrics, on the other hand, is the study of electronic information on the internet, using bibliometric methods (Björneborn, 2004). In the late 1990s, the web was suggested to be a medium through which the diverse impacts of scholars could be identified (Cronin, Snyder, Rosenbaum, Martinson, \& Callahan, 1998). As a result of this and other observations about the potential of the web for bibliometrics (e.g., Almind \& Ingwersen, 1997), the new area of webometrics emerged a sub-area of cybermetrics and informetrics for the study of web-based phenomena drawing upon bibliometric methods (Björneborn \& Ingwersen, 2004). Recently, with the advent of the social web, the new area of altmetrics began. Altmetrics focuses on social web sites like Twitter, blogs, Wikipedia, Mendeley and other social bookmarking tools and uses open APIs for data gathering (Priem, Taraborelli, Groth, \& Neylon, 2011). Like the web, social web platforms provide new opportunities to measure scholarly communication (Priem, 2013) in both formal and informal contexts (Cronin, 2013a). Rousseau and Ye (2013, p. 3289) believe that although the idea behind altmetrics is valuable, the term is not appropriate. They suggested "influmetrics" instead, as more explicitly a subdivision of webometrics. Similarly, Cronin (2013b, p.1523) argued that "complementary" can be a better term rather than alternative in this context.

Early altmetrics research characterised social media data and its appropriateness for research assessment. Social reference managers and social bookmarking tools such as Mendeley, CiteUlike, and BibSonomy provide facilities for users to save, manage and share scientific literature online. In addition, when users bookmark or save a record in their own social web profile then a reader count or bookmark will be recorded on the website. These social platforms thus provide opportunities to trace the global usage of scientific publications (Haustein et al., 2010). Some studies have used reference managers and social bookmarking websites to generate altmetrics. For example, several bookmarking-based metrics and some traditional indicators have been compared for assessing physics journals (Haustein \& Siebenlist, 2011).

Priem, Piwowar and Hemminger (2012) explored a large sample of papers published by the Public Library of Science (PLOS). Around $80 \%$ of the PLoS articles were covered by Mendeley while $31 \%$ and $10 \%$ of these papers were bookmarked on CiteULike and Delicious, respectively, although it is not completely fair to compare statistics between the sites because they are used and record information in different ways. Around $10 \%$ to $12 \%$ of the sample were tweeted or mentioned on Facebook and less than $10 \%$ of the papers were cited in blogs or reviewed by Faculty of 1000 (F1000, now F1000Prime), a post-publication review site for biomedical papers. Similarly, previous studies have reported that the coverage of Mendeley is more extensive than that of CiteULike for a sample of articles published in 
Science and Nature (Li et al., 2012) with similar results being found for publications in the field of bibliometrics (Haustein et al., 2013). It has also been reported that Mendeley had the highest coverage among other altmetrics resources for 20,000 random publications indexed in WoS (Zahedi, Costsas, \& Wouters, 2013). Furthermore, Mohammadi and Thelwall (in press) found that $44 \%$ of Social Science articles and $13 \%$ of the Humanities papers from WoS in the year 2008 were covered by Mendeley. In contrast, analysing the entire F1000 database, Waltman and Costas (in press) discovered that as few as $2 \%$ of biomedicine articles were reviewed by F1000 experts. Again, the figures are not directly comparable because F1000 articles are reviewed whereas Mendeley articles are only recorded in the site. A large-scale study of PubMed articles in 11 social media resources (excluding Mendeley) reported that less than $20 \%$ of the papers were covered by most of the resources (Thelwall, Haustein, Larivière, \& Sugimoto, 2013), with Twitter having the most extensive coverage at less than 10\% for 2010 to 2012 PubMed articles and reviews (Haustein, Peters, Sugimoto, Thelwall, \& Larivière, in press). In another large-scale multidisciplinary study, Costas, Zahedi, and Wouters, (2014) discovered that research papers had more coverage (13.3\%) in Twitter than in several other social websites, including Facebook walls, blogs, Twitter, Google+ and News outlets. A later Mendeley analysis of the same set of 1.4 million PubMed papers reports that $66 \%$ had at least one Mendeley reader (Haustein et al., submitted). Results of a survey of bibliometricians reported that most of them had LinkedIn profiles (68\%) and around half had Twitter accounts while $20 \%$ were users of Academia.edu, Mendeley, and ResearchGate (Haustein et al., 2013).

For research evaluation purposes, the value of different social web data should be validated. As a result, several studies have assessed the value of altmetrics-based indicators by comparing them with traditional metrics. One study, for example, found that tweet mentions of articles in a single open access online medical informatics journal could predict future citations (Eysenbach, 2011). Similarly, Shema, Bar-Ilan, and Thelwall (in press) reported that papers mentioned in science blogs received more citations later. Moderate correlations between F1000 scores and citations have also been reported (Waltman \& Costas, 2013; Li \& Thelwall, 2012) and F1000 scores are able to recognize the suitability of medical papers for clinical practice better than citations (Mohammadi \& Thelwall, 2013). Finding no correlations between indicators derived from the academic social web site Academia.edu and bibliometric indicators, Thelwall and Kousha (in press) concluded that the informal scholarly communications in Academia.edu probably do not reflect traditional academic impact or prestige. Significant positive correlations between bookmarking data from CiteUlike and Mendeley and citations for a sample of articles published in Science and Nature provide evidence that bookmarking data is a promising source for research evaluation ( $\mathrm{Li}$ et al., 2012). Nevertheless, based upon moderate correlations between Mendeley readership and citation counts for articles, Bar-Ilan (2012), Haustein et al. (2013), Haustein et al. (submitted) and Zahedi et al., (2013) all concluded that reading and citing are not similar scholarly activities. Li and Thelwall (2012) found positive correlations between Mendeley readership counts and bibliometric indicators for a sample of papers in the field of genomics and genetics. In two large-scale studies, medium positive correlations between Mendeley readership counts and citations were discovered for ten social science and humanities 
disciplines (Mohammadi \& Thelwall, in press) and PubMed papers (Haustein et al., submitted). Both studies concluded that readership and citations reflect different types of research impact. To sum up, although many metrics derived from social media have been shown to correlate with bibliometric indicators for some specific sets of articles, it is not clear what kinds of research impact can be captured through the new indicators. Thus, new studies are needed to investigate which kinds of research influence can be reflected by altmetrics.

\section{Professions and Science}

The responsibilities of different professions and the status of academics can both affect the roles and contexts in which individuals use scholarly publications. For example, younger researchers read more papers (Tenopir, King, Spencer, \& Wu, 2009) and also cite more resources in their publications (Pancheshnikov, 2007; Barnett \& Fink, 2008; Larivière, Sugimoto, \& Bergeron, 2013) in comparison to senior researchers. Niu and Hemminger (2012) found academic status to be an important issue in information seeking behaviour for faculty members, students and staff at five US universities. Interviewing scholars in the field of humanities, Ge (2010) revealed that $\mathrm{PhD}$ students and assistant professors use electronic resources more than associate professors and professors. Jamali and Nicholas (2006) found that $\mathrm{PhD}$ students browse electronic journals more than senior scholars in physics and astronomy. Catalano (2013) concluded that although Masters and $\mathrm{PhD}$ students both use the web for information searching, the latter believe that references provided by faculty members are more reliable. Whitmire (2002) argued that the information seeking behaviour of undergraduate students could be different from that of graduate students and faculty members but they can have similar information seeking behaviour because some students used resources suggested by faculty members more than other references (Korobili, Malliari, \& Zapounidou, 2011).

Outside academia, practitioners and developers use research publications in their daily activities (Bollen \& Van De Sompel, 2008) but the roles, tasks and the contexts in which they use information can affect their information seeking behaviours (Leckie, Pettigrew, \& Sylvain, 1996). For example, a survey of non-author physicians in Canada discovered that $73 \%$ of the participants read journal articles (McAlister, Graham, Karr, \& Laupacis, 1999). Another study reported that journal articles were the most useful publication type to fulfil the information needs of residents in a hospital (Schilling, Steiner, Lundahl, \& Anderson, 2005). The information seeking habits of engineers in different fields (Ellis \& Haugan., 1997; Kwasitsu, 2003; Freund, Toms, \& Waterhouse, 2005; Taylor et al., 2010) have also been examined. Personal communications with colleagues, internal documents, journal articles, conference proceedings are all sources that engineers use to satisfy their information needs (Hertzum \& Pejtersen, 2000). In principle, due to the practical nature of these professions they do not cite and may read less than university faculty members (Tenopir \& King, 2000 cited by Tenopir, King, Clarke, Na, \& Zhou, 2007). For instance, a survey of paediatricians at the University of Tennessee revealed that they read journal articles for updating their knowledge but read less than medical faculty members in the same organization (Tenopir et al., 2007). In summary, there is evidence that some professions outside academia read 
scientific articles and therefore the impact of these articles would not be fully reflected by citations - but little is known about how the impact of publications on different professions could be measured.

\section{Research Questions}

In order to holistically evaluate the use of research results, it is important to know who reads academic articles and why (Thelwall, 2012). These issues have not been systematically examined before, because of anonymity in usage data for electronic journals and because of the lack of usage data for print journals. Although some studies have explored article readership on a small scale (Niu \& Hemminger, 2012; Hemminger, Lu, Vaughan, \& Adams, 2007) there are no large-scale systematic studies of what types of people read scholarly articles. This study partly fills this gap from a quantitative perspective by analysing the statuses of readers (e.g., professors, PhD students, undergraduate students, non-academic users) of research articles for several disciplines in Mendeley. Additionally, the effect of users' occupations on correlations between Mendeley readership counts and citations investigated. The following research questions drive this study, focusing on several broad areas of science.

1. What are the common types of readers for Clinical Medicine, Engineering and Technology, Social Science, Physics and Chemistry research articles in Mendeley?

2. Does academic or professional status of readers in Mendeley affect the relationship between Mendeley readership counts and citation counts?

\section{Research method}

\section{Data collection}

The Web of Science (WoS) was chosen as the source of lists of articles in academic journals. The Observatoire des sciences et des technologies in-house version of the Thomson Reuters databases was used. All bibliographic information and citation data for WoS journal articles from 2008 was selected, excluding non-article document types, such as editorials and book reviews. The citation data comes from the Science Citation Index Expanded (SCIE), the Arts \& Humanities Citation Index (AHCI) and the Social Science Citation Index (SSCI) in December 2012. The year 2008 was chosen to allow all articles at least four years to receive citations. For defining the main research disciplines and sub-disciplines, the US National Science Foundation (NSF) classification was used. This classification is more suitable for this study than the WoS classifications because each journal is assigned to only one NSF research speciality or sub-discipline. The 22 most productive disciplines in terms of the number of publications in the year 2008 were selected for the study from the broad NSF categories of Clinical Medicine, Engineering and Technology, Social Science, Physics and Chemistry (see Appendix 1). These disciplines include 44\% of the journal articles from 2008 in the Thomson Reuters databases used. 
In the next step, using the Mendeley API, Mendeley readership counts for each selected WoS article were automatically extracted with Webometric Analyst (lexiurl.wlv.ac.uk) relying on a query based on the last name of the first author, publication year and title of the article. Instead of relying on a document identifier such as DOI, which is often missing in the Mendeley entries, this method increases recall by relying on three main metadata elements. However, documents with at least one incorrect item of bibliographic information (e.g., author or year) were ignored to increase precision. As multiple copies of a paper could exist in Mendeley, duplicate records were identified and removed based on WoS unique IDs. Out of 480,979 WoS articles for all disciplines, 219,326 (45.6\%) were found in Mendeley and 3,745 were duplicates. Removing duplicates reduced the overall readership count by $1.1 \%$ (see Table 4).

Mendeley coverage varied by discipline. Clinical Medicine articles had the highest coverage in Mendeley (71.6\% had a Mendeley record, see Table 1), while in Physics, Chemistry and Engineering and Technology only about one third of the documents were saved in Mendeley. Mendeley records with zero readers in the Mendeley database were disregarded. These papers could have been added to Mendeley in several ways. For instance, Mendeley may automatically add all articles from specific publishers. Moreover, some journals administrators or researchers may add all their publications to Mendeley to publicise them. Detailed information for articles with zero readers is listed in Table 1.As shown in Table 1, $41.1 \%$ of the WoS articles had Mendeley readership statistics. All of the 197,848 of the WoS articles with Mendeley readership statistics from Clinical Medicine, Engineering and Technology, Social Science, Physics and Chemistry were selected for further analysis (see appendix, Table 4).

Table 1. Coverage of WoS articles from Clinical Medicine, Engineering and Technology, Social Science, Physics and Chemistry in Mendeley.

\begin{tabular}{|c|c|c|c|c|c|}
\hline Discipline & $\begin{array}{c}\text { Articles } \\
\text { indexed } \\
\text { by WoS } \\
\text { in 2008 }\end{array}$ & $\begin{array}{c}\text { Unique } \\
\text { WoS } \\
\text { articles } \\
\text { covered } \\
\text { by } \\
\text { Mendeley }\end{array}$ & $\begin{array}{c}\text { Duplicate } \\
\text { WoS } \\
\text { records in } \\
\text { Mendeley }\end{array}$ & $\begin{array}{c}\text { Articles } \\
\text { with } \\
\text { readership } \\
\text { statistics } \\
\text { in } \\
\text { Mendeley }\end{array}$ & $\begin{array}{c}\text { Articles } \\
\text { without } \\
\text { readership } \\
\text { statistics }\end{array}$ \\
\hline $\begin{array}{c}\text { Clinical Medicine } \\
\text { Engineering and } \\
\text { Technology }\end{array}$ & 145,536 & $71.6 \%$ & $1.5 \%$ & $62.1 \%$ & $9.5 \%$ \\
\hline $\begin{array}{c}\text { Social Science } \\
\text { Physics }\end{array}$ & 109,390 & $34.8 \%$ & $1.5 \%$ & $32.6 \%$ & $2.2 \%$ \\
\hline Chemistry & 101,581 & $31.4 \%$ & $1.2 \%$ & $29.7 \%$ & $1.8 \%$ \\
\hline Total & 480,979 & $45.6 \%$ & $1.7 \%$ & $41.1 \%$ & $4.4 \%$ \\
\hline
\end{tabular}


Although the Mendeley API provides information related to the discipline, academic status and country of readers for each record, it only reports percentages rather than raw data and only gives information about the top three categories. For each article and each of the top three readers' occupations for that article, the percentage of readers with that occupation was multiplied by the total number of readers of the article and divided by 100 to obtain the estimated number of article readers from that occupation.

To understand how far the three most frequent statuses represented the entire readership of a document, the sum of the (up to) three status percentages was subtracted from the total readership counts to indicate the missing information per document. As shown in Table 2, academic status information was not available for $27 \%$ of the total readership counts due to the restrictions of the Mendeley API.

Table 2. Available and missing Mendeley user status information for readership counts for Clinical Medicine, Engineering and Technology, Social Science, Physics and Chemistry via the Mendeley

API.

\begin{tabular}{|l|l|l|l|}
\hline Discipline & $\begin{array}{l}\text { Total readership } \\
\text { counts }\end{array}$ & $\begin{array}{l}\text { Readership counts } \\
\text { with status } \\
\text { information available } \\
\text { via the API for the } \\
\text { top 3 categories }\end{array}$ & $\begin{array}{l}\text { Readership } \\
\text { counts without } \\
\text { status information }\end{array}$ \\
\hline Clinical Medicine & 699681 & $70.5 \%$ & $29.4 \%$ \\
\hline $\begin{array}{l}\text { Engineering and } \\
\text { Technology }\end{array}$ & 324624 & $75.2 \%$ & $24.7 \%$ \\
\hline Social Science & 140952 & $69.0 \%$ & $31.1 \%$ \\
\hline Physics & 251071 & $76.5 \%$ & $23.4 \%$ \\
\hline Chemistry & 231313 & $76.9 \%$ & $24.3 \%$ \\
\hline Total & 1647641 & $73.1 \%$ & $27.0 \%$ \\
\hline
\end{tabular}

Some of the 15 occupational categories reported by Mendeley are similar and were merged into a single category. For instance, postgraduate students and masters students were merged into a single postgraduate student category (see appendix, Table 5).

\section{Results}

\section{Readers and occupations}

Because Mendeley only reports reader counts for the top 3 occupational categories for each article and this biases the results so that they underestimate the percentages of categories which frequently do not belong to the top 3, results are also provided for documents where the top 3 categories made up $100 \%$ and at least $66 \%$ of all reader counts, respectively. As the 
actual unbiased percentage of readers per status cannot be exactly determined based on the data provided, the three values can thus be considered as estimates of actual values, where the true figure lies somewhere between the three values for each occupation.

Figure 1 shows that in all disciplines $\mathrm{PhD}$ students were the main Mendeley readers of articles in 2008 for all papers, papers with at least 66\% and papers with $100 \%$ reader counts, although the percentages vary across different disciplines. Postgraduate students and Postdocs were the main readers after $\mathrm{PhD}$ students across different disciplines, as shown in Figure 1 and tables 5, 6 and 7. All of the professions are self-reported and it is possible that, for example, some of the people recorded as Professor might not be full professors. Moreover, people with other academic ranks, such as Reader or Lecturer in the UK, might not map themselves accurately to the most similar Mendeley category.
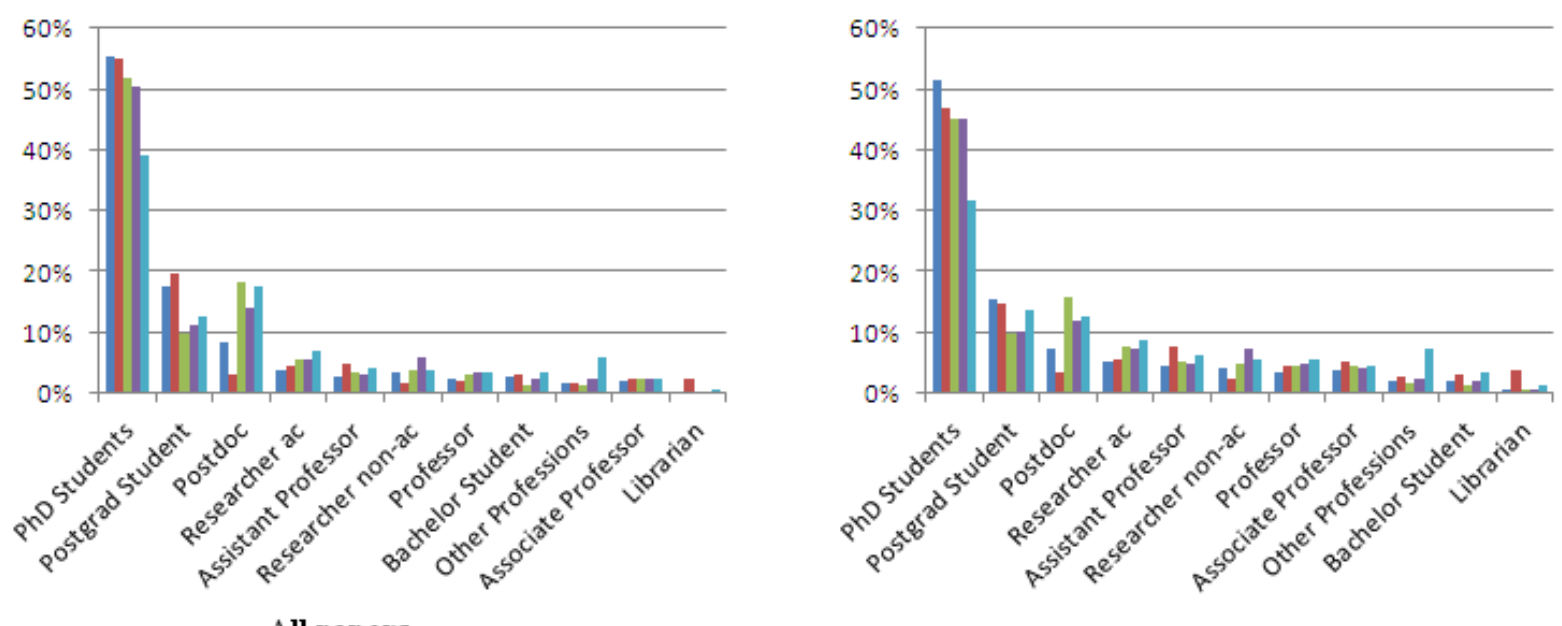

Papers with $100 \%$ reader counts
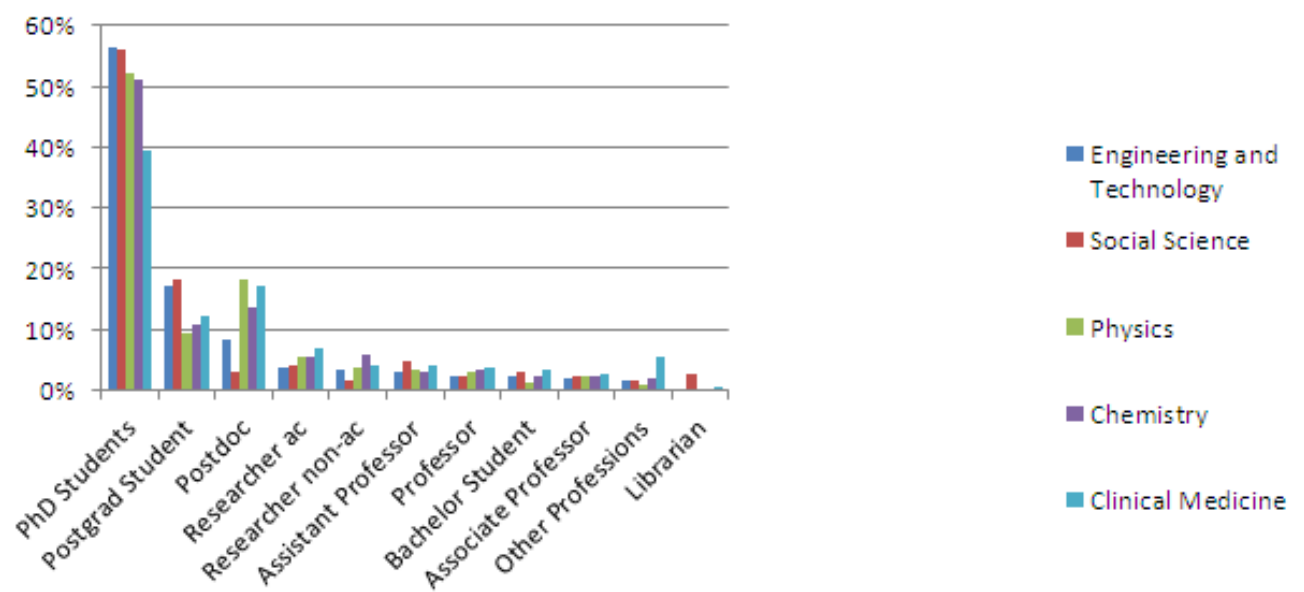

Papers with at least $66 \%$ reader counts

Figure 1. Readers of WoS articles from Clinical Medicine, Engineering and Technology, Social Science, Physics and Chemistry in Mendeley based on academic status for all papers, and for papers with $66 \%$ and $100 \%$ readership counts. 
Among the selected disciplines, about $7.2 \%, 5.9 \%$ and $5.6 \%$ of the readers of Clinical Medicine papers were from the Other Professions category for papers with $100 \%$, all papers and papers with $66 \%$ reader counts respectively.. Librarians were 3.7\%, 2.8\% and $2.5 \%$ the reported readers of social sciences articles but were the least common readers of papers in other disciplines.

Correlations between Mendeley readership counts and citations based on users' occupations Spearman correlations were calculated for each sub-discipline between Mendeley readership counts and citations for all articles with at least one reader in Mendeley. Values of $\mathrm{r}=0.1+$, $0.3+$, and $0.5+$ (whether positive or negative) were considered to be small, medium, and large, respectively (Cohen, 1988), with medium and large correlations considered to be substantial. There were statistically significant and substantial correlations between Mendeley readership counts and citations for all five disciplines (Table 3, see also Table 9). The correlations for all of the disciplines are similar but are highest in Clinical Medicine and Social Science $(r=.561)$.

In order to investigate the effect of non-read articles on correlations between Mendeley readership counts and citations, the analysis was repeated but including articles with zero readers (including articles that were in Mendeley but which were not found by the search process). In other words, all articles not found in Mendeley were assumed to have zero Mendeley readers. As shown in Table 3 the correlations between Mendeley readership counts and citations are weaker for all examined disciplines. The median Mendeley readership counts for all Social Science sub-disciplines are higher than their median citation counts and the overall median Social Science Mendeley readership count is double the median Social Science citation count (Table 3). The opposite is true for Physics, Chemistry and Clinical medicine but there is equality in Engineering and Technology. If the dataset had included articles with zero Mendeley readership counts, then the correlations would probably have been weaker (Mohammadi \& Thelwall, in press), as confirmed below.

Table 3. Spearman correlations between WoS citations and Mendeley readership counts (both zero and non-zero) for 2008 articles.

\begin{tabular}{|l|l|l|l|}
\hline $\begin{array}{l}\text { Main } \\
\text { disciplines }\end{array}$ & $\begin{array}{l}\text { WoS citation median } \\
\text { non-zero only/ Both } \\
\text { zero and non-zero }\end{array}$ & $\begin{array}{l}\text { Mendeley readership } \\
\text { median } \\
\text { non-zero/ Both zero and } \\
\text { non-zero }\end{array}$ & $\begin{array}{l}\text { Spearman } \\
\text { correlation } \\
\text { non-zero/ } \\
\text { zero and non-zero } \\
\text { Both }\end{array}$ \\
\hline Clinical & 9 & 4 & $.561^{* *}$ \\
Medicine & 7 & 5 & $.463^{* *}$ \\
\hline Engineering and & 3 & 2 & $.501^{* *}$ \\
Technology & 4 & 5 & $.37^{* *}$ \\
\hline Social Science & 2 & 0 & $.561^{* *}$ \\
& 7 & 8 & $.456^{* *}$ \\
\hline Physics & 4 & 0 & $.548^{* *}$ \\
& 11 & 5 & $.308^{* *}$ \\
\hline Chemistry & 6 & 0 & $.554^{* *}$ \\
& & 5 & $.369^{* *}$ \\
\hline
\end{tabular}

**Significant at $\mathrm{p}=0.01$ 
As mentioned before, only the top three occupations for Mendeley readership counts are available for each article. To partly overcome this limitation, correlations were calculated between Mendeley readership counts and citations for several occupations for three datasets based on the availability of readership data, including a) all articles, b) articles with at least $66 \%$ of reader occupations available, and c) articles with $100 \%$ of reader occupations available. The correlations for all papers are presumably overestimates, especially for those occupational categories that often do not belong to the top 3 reported ones. As the actual unbiased correlation values cannot be computed, the three values are considered as estimates where the $100 \%$ value reflects the lower bound of correlations.

There are positive correlations between Mendeley readership counts and citations for almost all the occupations, except librarians for some sub-disciplines, although the strengths of the correlations vary by occupation across the research disciplines (Figure 2). As shown in Figure 2 , the correlations decrease for records with $66 \%$ of the readership occupations available in comparison to all articles and the correlations are smaller for records with $100 \%$ of the readership occupations available in contrast to the sets of articles with at least $66 \%$ of the readership occupations available. In other words, all correlations are lower for papers with $100 \%$ readership occupations available and the likely reason is that these papers are the least cited papers with the lowest total number of readers and so the correlation test is less powerful for them because the numbers are smaller. Generally, the highest correlations are for full professors, assistant professors, postdocs and $\mathrm{PhD}$ students while the lowest correlations are for undergraduates, other professions and librarians in all disciplines in all the three datasets. The pattern of correlations for researchers at academic and non-academic institutions is similar across the research areas for all the three datasets. However, the differences between correlations for undergraduate and postgraduate students are noticeable for all disciplines (see appendix, Tables 10,11 and 12). The correlations between Mendeley readership counts and citations for full professors, assistant professors, post docs and $\mathrm{PhD}$ students, postgraduate students are substantial for all disciplines. As shown in Figure 2, the correlations for undergraduates and other professions are small. Nevertheless, the correlations for other professions are higher for Clinical Medicine among the other disciplines. 


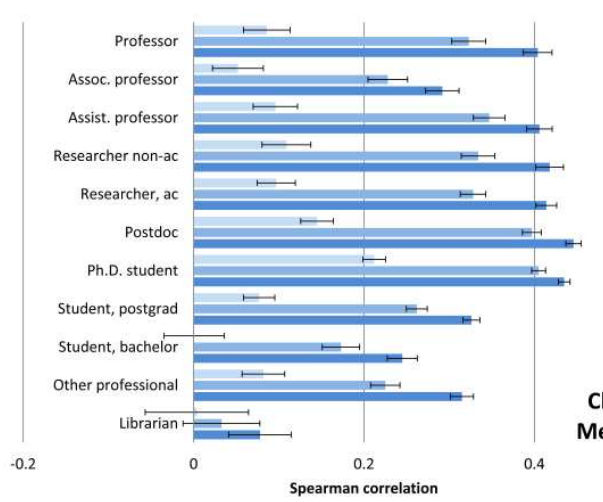

" papers with 100\% reader counts = papers with at least $66 \%$ reader counts = all papers

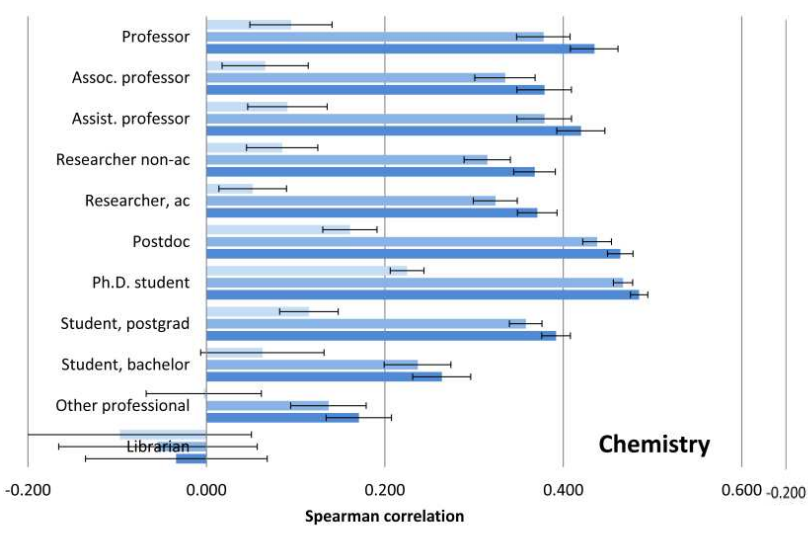

papers with $100 \%$ reader counts $=$ papers with at least $66 \%$ reader counts $\mid$ all papers

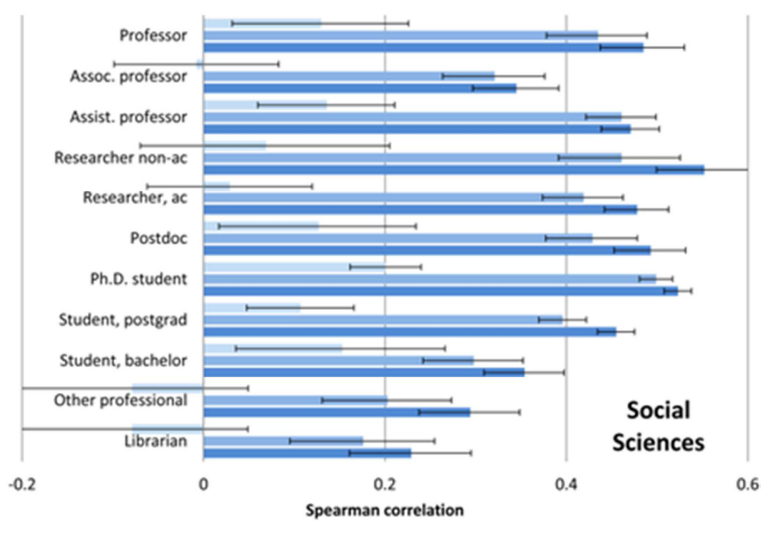

papers with $100 \%$ reader counts $=$ papers with at least $66 \%$ reader counts $=$ all papers

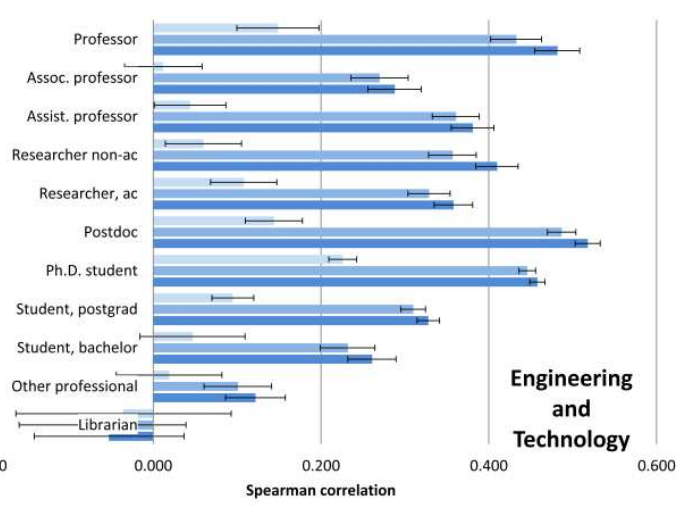

" papers with $100 \%$ reader counts " papers with at least $66 \%$ reader counts "| all papers

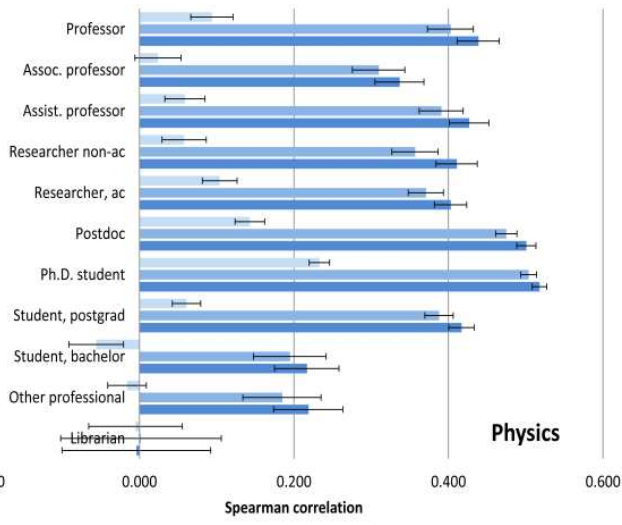

" papers with 100\% reader counts $=$ papers with at least $66 \%$ reader counts || all papers

Figure 2. Spearman correlations between Mendeley readership counts and citations based on occupations for Clinical Medicine, Engineering and Technology, Social Science, Physics and Chemistry. Figures are reported separately for three data sets determined by the percentage of reader occupations known for an article. Error bars give a 95\% confidence interval, calculated using a Fisher transformation of the correlation to give it an approximately normal distribution. 


\section{Discussion}

Most readers of Clinical Medicine, Engineering and Technology, Social Science, Physics and Chemistry papers in Mendeley are PhD students. Postgraduate students and postdoctoral researchers are the two most common readers of papers in Mendeley across different disciplines, after PhD students. Perhaps the most important reason is that Mendeley attracts young researchers because they adapt to new technology better than older scholars. Another possible explanation is that $\mathrm{PhD}$ students and postdoctoral researchers mainly research whereas the other groups are likely to have more additional responsibilities. Also, $\mathrm{PhD}$ students use more references in their publications than do faculty members (Larivière, Sugimoto, \& Bergeron, 2013). Additionally, $\mathrm{PhD}$ students and postdoctoral researchers mine the literature more than senior researchers as they try to obtain comprehensive knowledge about their research topics while older researchers are often co-authors (Gingras, Larivière, Macaluso, \& Robitaille, 2008) and thus probably have more supervisory roles in research projects. Alternatively, younger researchers are more adaptable to novel ideas and read more new publications, while senior scholars use older literature (Barnett \& Fink, 2008). Moreover, Mendeley is a new tool and senior researchers seem to avoid using most social web services (Mas-Bleda, Thelwall, Kousha, \& Aguillo, 2013) and may prefer to continue with their existing referencing practices.

Postgraduates are also readers of many articles in almost all of the sub-disciplines. They are not far behind $\mathrm{PhD}$ students in terms of using Mendeley. Additionally, whilst undergraduates are Mendeley readers of scholarly articles, their scarcity compared to postgraduate and $\mathrm{PhD}$ students could be because undergraduates tend to use reference materials and textbooks (Jamali \& Nicholas, 2006) rather than journal articles as the former provide their information in a more convenient way (Fescemyer, 2000) or they do not yet know about reference management software.

A noticeable percentage of Clinical Medicine papers were read by people who are apparently not academics and this is an important issue because some articles could be useful in clinical practice even if they are not cited in the literature (Jones, Donovan, \& Hanney, 2012). Moreover, a noticeable fraction of the social science papers, probably Library and Information Science articles, had librarians as readers, which is consistent with results of Schloegl and Stock (2004). Additionally, librarians bookmarked some Clinical Medicine papers and this could be an indication of medical researchers engaging clinical librarians in scholarly activities like systematic searching and information dissemination. The importance of these kinds of scholarly activities by librarians has been mentioned before (Brettle \& Long, 2001).

There were substantial and positive correlations between Mendeley readership and citation counts for all the studied sub-disciplines of Clinical Medicine, Engineering and Technology, Social Science, Physics and Chemistry. These findings corroborate previous studies (BarIlan, 2012; Li et al., 2012; Mohammadi \& Thelwall, in press) but stronger correlations were found for this dataset. A probable likely reason for the increased correlation is that the number of Mendeley users has increased over time, giving better raw readership data. As reported above, the correlations vary across different sub-disciplines. 
The median Mendeley readership counts for all Social Science and some Engineering and Technology sub-disciplines are significantly higher than the median number of citations. The results could be evidence that papers in these research areas were read by many people that did not cite them, consistent with Social Science articles having many pure readers (Armbruster, 2008) and Engineering and Technology papers being used in applied contexts. Thus, it seems that Mendeley readership is able to provide evidence of using research articles in contexts other than for their science contribution, at least for Social Science and some applied sub-disciplines. Therefore, and since citation-based indicators are less effective for Social Science research evaluation than for hard Sciences research evaluation (Nederhof, 2006), Mendeley readership could compliment citations for the evaluation of Social Science articles. Moreover, it also could be used as a supplementary indicator to measure the impact of some technological or medical papers in applied contexts, as citation analysis is more useful for the assessment of theoretical research rather than applied research.

In response to the second research question, the findings indicate that there are positive correlations between Mendeley readership and citations for all of the occupations, except librarians, for all of the sub-disciplines examined. However, the highest correlations are for users that are also authors, except for associate professors in some sub-disciplines. This suggests that Mendeley readers with authorship roles probably reflect impact closer to traditional citations in comparison to readership counts for non-author types of user and goes some way towards validating Mendeley as an altmetric data source. Nevertheless, the correlations for authors are not strong enough to claim that Mendeley readership counts and citation counts are interchangeable. It is likely that academics use research articles in other activities rather than citing, for example in their teaching. The lowest correlations were found for undergraduates and non-academic users. This suggests that students often benefit from articles that are not highly cited. Thus, Mendeley provides an opportunity to monitor impact on students, which probably reflects the educational value of research articles. This would only work for a small percentage of articles, however, since undergraduates are a small minority of Mendeley users and their data is typically hidden by Mendeley as a side-effect of reporting only the three most common types of user for each article. A logical consequence of this is that low citations for undergraduate users may partly be an artefact of readership counts for undergraduate only registering in the Mendeley API when undergraduate form a disproportionately high proportion of an article's readers. Similarly, non-academic readership counts have among the lowest correlations with citation counts, suggesting that their readership counts could also help to identify individual articles and types of article that are valuable outside academia.

The results of this study are consistent with conclusions of Kurtz and Bollen (2010), which were based on case studies (e.g. Rowlands \& Nicholas, 2007; Bollen \& Van De Sompel, 2008) using usage datasets that were mainly local (institutional), publisher dependent and not publically-accessible, and therefore not practical for most researchers. Thus, this research gives a practical solution with global usage data for multiple disciplines for the first time.

One of the limitations of this research is that the sample is restricted to journal articles while users in particular occupations or disciplines may benefit more from other document types. 
For example, engineers read relatively many conference articles in comparison to books and journals (Niu \& Hemminger, 2012). Based upon advanced Mendeley searches for WoS journal articles from 2008, it seems that Mendeley has records for 837,958 journal articles from 2008, although some of these records are likely to be duplicates and so the actual number of journal articles in Mendeley is likely to be lower than this. . Within these articles, 788,260 (94\%) had at least one Mendeley reader. The current study main sample includes the 197,848 WoS articles from 2008 from Clinical Medicine, Engineering and Technology, Social Science, Physics and Chemistry with at least one Mendeley reader, which is about $25 \%$ of in the articles from 2008 with at least one Mendeley reader.

Another limitation is that it compares individual readership counts of each article with the total citations received by an article instead of the unique number of citing authors. The latter would involve author disambiguation, which was not feasible given the large amount of citing papers. As mentioned above, data on readers' occupations was only available for three most common reader categories for each article, which resulted in losing around $27 \%$ of the readership counts. A consequence of this is that numerically small groups of readers (e.g., associate professors, professors, undergraduates, librarians), may have lower correlations due to underestimating their readership or only recording their readership values for articles for which they formed a disproportionately large share of the readers. Perhaps most importantly, the site Mendeley is perhaps most useful for those who will eventually cite an article and so its readership counts seem likely to under-represent users who will never need to cite an article, perhaps including disproportionately many practitioners. Hence Mendeley readership statistics should not be taken as an unbiased reflection of an article's readers.

Finally, from the perspective of using Mendeley as a data source for altmetrics, the biggest limitation is that probably the users of Mendeley form a small and biased minority of the readers of academic articles. In particular, assuming that Mendeley users tend to be younger than typical article readers, Mendeley readership data could not be used to estimate the proportions of readers of different types for articles. For example, although various types of professor form less than $10 \%$ of the Mendeley readers of articles and various types of student form 55\%-77\% (depending upon area), it is possible that professors are the majority readers of articles but rarely join Mendeley. Nevertheless, it seems reasonable to compare the proportions of Mendeley readers with different occupations between sets of articles in Mendeley (e.g., Social Sciences vs. Clinical Medicine) to identify whether readership is particularly high for one occupational group, even though the level of uptake of Mendeley between different professions could also vary between discipline.

\section{Conclusions}

This study suggests that the Mendeley readership consists of many undergraduate and postgraduate students, as well different groups of academics and non-academics. In other words, the results show that Mendeley provides evidence that research articles are read by a variety types of users inside and outside academia. A majority of Mendeley readers are PhD students in Engineering and Technology, Social Science, Physics and Chemistry, with faculty, perhaps surprisingly, being a minority in all cases. In terms of Mendeley readers outside of higher education institutions, these appear to be a small minority, with Clinical 
Medicine having $7.2 \%$ from Other professions for papers with 100\% readership counts. Thus, Mendeley readership is able to capture a dimension of the impact of scientific documents on various activities performed within the academic community - such as "plain reading", i.e., reading without subsequently citing, writing theses, doing assignments or drafting research proposals but also provides a little evidence of their applied use by people outside academia, such as medical doctors and surgeons.

Mendeley readership counts could perhaps supplement citation counts in the Social Sciences and in some Engineering research areas in which citation counts are lower than Mendeley readership counts. The variation in correlations between Mendeley readership counts and citations received for different types of reader suggested that the meaning of Mendeley readership counts depends upon the readers' occupations. This implies that in some cases Mendeley readership may reflect traditional citation impact but in other cases it may reflect educational uses or impact on applied contexts. Therefore, Mendeley readership is a promising data source that is different from both citations and raw usage data. However, Mendeley is only one of many reference manager tools and other reference managers (e.g. Endnote, RefWorks, Zotero) also have many users but their data are not publically available. Thus, Mendeley seems to be the only choice to reveal aspects of the readership of research articles. This could be particularly useful in disciplines for which citation-based indicators are least reliable, such as the social sciences, arts and humanities, and perhaps also applied research. Nevertheless, more qualitative research is needed to investigate why Mendeley users register articles in order to find out how often adding a document to the Mendeley library means that the document has been, or will be, read. 


\section{Appendices}

Table 4. Coverage of WoS articles from Clinical Medicine, Engineering and Technology, Social Science, Physics and Chemistry in Mendeley (detailed version).

\begin{tabular}{|c|c|c|c|c|c|c|c|}
\hline Sub-discipline & $\begin{array}{l}\text { Article } \\
\text { s } \\
\text { indexe } \\
d \text { by } \\
\text { WoS in } \\
2008\end{array}$ & $\begin{array}{l}\text { Unique } \\
\text { WoS } \\
\text { articles } \\
\text { covered } \\
\text { by } \\
\text { Mendel } \\
\text { ey }\end{array}$ & $\begin{array}{l}\text { Duplicate } \\
\mathrm{d} \text { records } \\
\text { in } \\
\text { Mendeley }\end{array}$ & $\begin{array}{l}\text { Articles } \\
\text { with } \\
\text { readersh } \\
\text { ip } \\
\text { statistics } \\
\text { in } \\
\text { Mendele } \\
\text { y }\end{array}$ & $\begin{array}{l}\text { Articles } \\
\text { without } \\
\text { readershi } \\
\text { p } \\
\text { statistics }\end{array}$ & $\begin{array}{l}\text { Total } \\
\text { readership } \\
\text { including } \\
\text { duplicates }\end{array}$ & $\begin{array}{l}\text { Lost } \\
\text { readership } \\
\text { counts } \\
\text { after } \\
\text { removing } \\
\text { duplicates }\end{array}$ \\
\hline $\begin{array}{l}\text { Neurology \& } \\
\text { Neurosurgery }\end{array}$ & 31616 & $77.8 \%$ & $0.0 \%$ & $73.0 \%$ & $4.7 \%$ & 288730 & $0.3 \%$ \\
\hline Pharmacology & 23276 & $67.7 \%$ & $1.1 \%$ & $60.8 \%$ & $6.9 \%$ & 77833 & $1.1 \%$ \\
\hline $\begin{array}{l}\text { General \& Internal } \\
\text { Medicine }\end{array}$ & 22410 & $65.1 \%$ & $5.7 \%$ & $56.7 \%$ & $8.3 \%$ & 98005 & $5.5 \%$ \\
\hline Cancer & 19440 & $73.8 \%$ & $0.4 \%$ & $67.4 \%$ & $6.3 \%$ & 85627 & $0.7 \%$ \\
\hline Surgery & 16961 & $71.9 \%$ & $0.8 \%$ & $49.1 \%$ & $22.7 \%$ & 32396 & $0.4 \%$ \\
\hline Immunology & 16822 & $73.2 \%$ & $0.5 \%$ & $67.5 \%$ & $5.7 \%$ & 79388 & $0.3 \%$ \\
\hline Cardiovascular System & 15011 & $68.7 \%$ & $1.7 \%$ & $50.4 \%$ & $18.3 \%$ & 41586 & $1.7 \%$ \\
\hline All & 145,536 & $71.5 \%$ & $1.5 \%$ & $62.0 \%$ & $9.5 \%$ & 703565 & $1.3 \%$ \\
\hline Mechanical Engineering & 13669 & $20.9 \%$ & $2.9 \%$ & $19.8 \%$ & $1.1 \%$ & 17620 & $0.5 \%$ \\
\hline Computers & 17768 & $43.2 \%$ & $1.9 \%$ & $41.6 \%$ & $1.6 \%$ & 94350 & $0.7 \%$ \\
\hline Electrical Engineering & 30271 & $40.4 \%$ & $0.6 \%$ & $35.7 \%$ & $4.7 \%$ & 65842 & $0.6 \%$ \\
\hline Chemical Engineering & 13486 & $26.7 \%$ & $1.0 \%$ & $26.1 \%$ & $0.6 \%$ & 25857 & $0.4 \%$ \\
\hline Materials Science & 34196 & $34.1 \%$ & $1.8 \%$ & $32.6 \%$ & $1.4 \%$ & 123535 & $0.9 \%$ \\
\hline All & 109390 & $34.8 \%$ & $1.5 \%$ & $32.5 \%$ & $2.2 \%$ & 327204 & $0.7 \%$ \\
\hline Economics & 12300 & $41.0 \%$ & $3.2 \%$ & $40.2 \%$ & $0.7 \%$ & 63950 & $1.7 \%$ \\
\hline General Social Science & 2628 & $40.3 \%$ & $2.40 \%$ & $39.6 \%$ & $0.6 \%$ & 11579 & $1.4 \%$ \\
\hline Education & 6620 & $54.6 \%$ & $6.8 \%$ & $53.9 \%$ & $0 . \%$ & 49610 & $4.4 \%$ \\
\hline LIS & 2330 & $62.1 \%$ & $6.4 \%$ & $59.5 \%$ & $2.6 \%$ & 20183 & $3.1 \%$ \\
\hline All & 23878 & $46.7 \%$ & $4.8 \%$ & $45.8 \%$ & $0.9 \%$ & 145322 & $2.8 \%$ \\
\hline Applied Physics & 29679 & $32.6 \%$ & $1.2 \%$ & $30.4 \%$ & $2.1 \%$ & 71050 & $0.6 \%$ \\
\hline General Physics & 36595 & $29.0 \%$ & $1.4 \%$ & $27.7 \%$ & $1.2 \%$ & 94520 & $0.6 \%$ \\
\hline $\begin{array}{l}\text { Nuclear \& Particle } \\
\text { Physics }\end{array}$ & 10381 & $16.5 \%$ & $0.8 \%$ & $14.9 \%$ & $1.5 \%$ & 5225 & $0.8 \%$ \\
\hline Optics & 14229 & $46.9 \%$ & $0.8 \%$ & $43.4 \%$ & $3.50 \%$ & 48614 & $0.5 \%$ \\
\hline Solid State Physics & 10697 & $30.0 \%$ & $1.6 \%$ & $29.6 \%$ & $0.4 \%$ & 33385 & $0.9 \%$ \\
\hline All & 101581 & $31.4 \%$ & $1.2 \%$ & $29.6 \%$ & $1.7 \%$ & 252794 & $0.6 \%$ \\
\hline General Chemistry & 23144 & $29.9 \%$ & $2.3 \%$ & $28.8 \%$ & $1.1 \%$ & 70228 & $1.0 \%$ \\
\hline Polymers & 12247 & $22.7 \%$ & $3.2 \%$ & $22.0 \%$ & $0.7 \%$ & 19478 & $1.6 \%$ \\
\hline Physical Chemistry & 36329 & $35.4 \%$ & $1.3 \%$ & $31.0 \%$ & $4.3 \%$ & 85717 & $0.5 \%$ \\
\hline Organic Chemistry & 16854 & $28.8 \%$ & $1.1 \%$ & $26.9 \%$ & $1.8 \%$ & 24190 & $0.6 \%$ \\
\hline Analytical Chemistry & 12020 & $53.3 \%$ & $1.3 \%$ & $46.4 \%$ & $6.9 \%$ & 36767 & $0.9 \%$ \\
\hline All & 100594 & $33.6 \%$ & $1.6 \%$ & $30.6 \%$ & $3.0 \%$ & 236380 & $0.8 \%$ \\
\hline Total & 480,979 & $45.6 \%$ & $1.7 \%$ & $41.1 \%$ & $4.4 \%$ & $1,665,265$ & $1.1 \%$ \\
\hline
\end{tabular}


Table 5. Complete and merged categories for Mendeley readers' occupations.

\begin{tabular}{|c|c|}
\hline $\begin{array}{l}\text { Occupation provided by the } \\
\text { Mendeley API }\end{array}$ & Merged \\
\hline Assistant Professor & \multirow{2}{*}{ Assistant Professor } \\
\hline Lecturer & \\
\hline Associate Professor & \multirow{2}{*}{ Associate Professor } \\
\hline Senior Lecturer & \\
\hline Librarian & Librarian \\
\hline Other Professions & Other Professions \\
\hline PhD Student & \multirow{2}{*}{ PhD Student } \\
\hline Doctoral Student & \\
\hline Postdoc & Postdoc \\
\hline Professor & Professor \\
\hline $\begin{array}{l}\text { Researcher (at a non-Academic } \\
\text { Institution) }\end{array}$ & $\begin{array}{l}\text { Researcher (at a non-Academic } \\
\text { Institution) }\end{array}$ \\
\hline $\begin{array}{l}\text { Researcher (at an Academic } \\
\text { Institution) }\end{array}$ & $\begin{array}{l}\text { Researcher (at an Academic } \\
\text { Institution) }\end{array}$ \\
\hline Student (Bachelor) & Student (Bachelor) \\
\hline Student (Postgraduate) & \multirow{2}{*}{ Student (Postgraduate) } \\
\hline Student (Master) & \\
\hline
\end{tabular}

Table 6. Readers of WoS articles from Clinical Medicine, Engineering and Technology, Social Science, Physics and Chemistry in Mendeley based on academic status for all papers regardless of $\%$ of available readership

\begin{tabular}{|l|l|l|l|l|l|}
\hline & $\begin{array}{l}\text { \%Engineering and } \\
\text { Technology }\end{array}$ & $\begin{array}{l}\text { \%Social } \\
\text { Science }\end{array}$ & \%Physics & \%Chemistry & $\begin{array}{l}\text { \%Clinical } \\
\text { Medicine }\end{array}$ \\
\hline PhD Students & $55.4 \%$ & $54.9 \%$ & $51.7 \%$ & $50.3 \%$ & $39.1 \%$ \\
\hline Postgrad Student & $17.4 \%$ & $19.5 \%$ & $9.6 \%$ & $11.1 \%$ & $12.6 \%$ \\
\hline Postdoc & $8.5 \%$ & $3.0 \%$ & $18.2 \%$ & $13.9 \%$ & $17.4 \%$ \\
\hline Researcher ac & $3.8 \%$ & $4.4 \%$ & $5.5 \%$ & $5.4 \%$ & $6.9 \%$ \\
\hline Assistant Professor & $2.9 \%$ & $4.9 \%$ & $3.4 \%$ & $3.1 \%$ & $4.2 \%$ \\
\hline Researcher non-ac & $3.3 \%$ & $1.7 \%$ & $3.7 \%$ & $5.8 \%$ & $3.9 \%$ \\
\hline Professor & $2.2 \%$ & $2.1 \%$ & $2.9 \%$ & $3.3 \%$ & $3.3 \%$ \\
\hline Bachelor Student & $2.8 \%$ & $3.0 \%$ & $1.4 \%$ & $2.4 \%$ & $3.5 \%$ \\
\hline Other Professions & $1.7 \%$ & $1.7 \%$ & $1.1 \%$ & $2.2 \%$ & $5.9 \%$ \\
\hline Associate Professor & $1.8 \%$ & $2.3 \%$ & $2.2 \%$ & $2.4 \%$ & $2.4 \%$ \\
\hline Librarian & $0.2 \%$ & $2.5 \%$ & $0.2 \%$ & $0.2 \%$ & $0.75 \%$ \\
\hline $\begin{array}{l}\text { Total individual readership } \\
\text { counts }\end{array}$ & 244,097 & 97,191 & 192,222 & 177,909 & 457,954 \\
\hline
\end{tabular}


Table 7. Readers of WoS articles from Clinical Medicine, Engineering and Technology, Social Science, Physics and Chemistry in Mendeley based on academic status for with $66 \%$ reader counts.

\begin{tabular}{|l|l|l|l|l|l|}
\hline & $\begin{array}{l}\text { Engineering } \\
\text { and } \\
\text { Technology }\end{array}$ & $\begin{array}{l}\text { Social } \\
\text { Science }\end{array}$ & Physics & Chemistry & $\begin{array}{l}\text { Clinical } \\
\text { Medicine }\end{array}$ \\
\hline PhD Students & $56.3 \%$ & $56.1 \%$ & $52.1 \%$ & $51.0 \%$ & $39.5 \%$ \\
\hline Postgrad Student & $17.0 \%$ & $18.3 \%$ & $9.3 \%$ & $10.7 \%$ & $12.1 \%$ \\
\hline Postdoc & $8.3 \%$ & $2.9 \%$ & $18.2 \%$ & $13.7 \%$ & $17.2 \%$ \\
\hline Researcher ac & $3.9 \%$ & $4.3 \%$ & $5.6 \%$ & $5.5 \%$ & $7.0 \%$ \\
\hline Researcher non-ac & $3.3 \%$ & $1.5 \%$ & $3.7 \%$ & $5.9 \%$ & $4.2 \%$ \\
\hline Assistant Professor & $2.9 \%$ & $4.9 \%$ & $3.3 \%$ & $3.0 \%$ & $4.2 \%$ \\
\hline Professor & $2.2 \%$ & $2.3 \%$ & $3.0 \%$ & $3.4 \%$ & $3.6 \%$ \\
\hline Bachelor Student & $2.4 \%$ & $2.9 \%$ & $1.3 \%$ & $2.2 \%$ & $3.3 \%$ \\
\hline Associate Professor & $1.9 \%$ & $2.4 \%$ & $2.3 \%$ & $2.5 \%$ & $2.6 \%$ \\
\hline Other Professions & $1.5 \%$ & $1.6 \%$ & $1.1 \%$ & $2.0 \%$ & $5.6 \%$ \\
\hline Librarian & $0.2 \%$ & $2.8 \%$ & $0.2 \%$ & $0.2 \%$ & $0.7 \%$ \\
\hline Total individual readership counts & 194,128 & 60,874 & 159,507 & 142,919 & 302,814 \\
\hline
\end{tabular}

Table 8. Readers of WoS articles from Clinical Medicine, Engineering and Technology, Social Science, Physics and Chemistry in Mendeley based on academic status for with $100 \%$ reader counts.

\begin{tabular}{|l|l|l|l|l|l|}
\hline & $\begin{array}{l}\text { Engineering } \\
\text { and } \\
\text { Technology }\end{array}$ & $\begin{array}{l}\text { Social } \\
\text { Science }\end{array}$ & Physics & Chemistry & Clinical Medicine \\
\hline PhD Students & $51.4 \%$ & $46.9 \%$ & $45.1 \%$ & $45.2 \%$ & $31.5 \%$ \\
\hline Postgrad Student & $15.5 \%$ & $14.8 \%$ & $9.6 \%$ & $10.0 \%$ & $13.8 \%$ \\
\hline Postdoc & $7.3 \%$ & $3.5 \%$ & $15.7 \%$ & $11.8 \%$ & $12.6 \%$ \\
\hline Researcher ac & $5.3 \%$ & $5.6 \%$ & $7.5 \%$ & $7.2 \%$ & $8.7 \%$ \\
\hline Assistant Professor & $4.5 \%$ & $7.6 \%$ & $5.0 \%$ & $4.9 \%$ & $6.1 \%$ \\
\hline Researcher non-ac & $4.2 \%$ & $2.3 \%$ & $4.7 \%$ & $7.2 \%$ & $5.4 \%$ \\
\hline Professor & $3.4 \%$ & $4.6 \%$ & $4.6 \%$ & $4.8 \%$ & $5.5 \%$ \\
\hline Associate Professor & $3.8 \%$ & $5.2 \%$ & $4.4 \%$ & $4.1 \%$ & $4.6 \%$ \\
\hline Other Professions & $2.0 \%$ & $2.5 \%$ & $1.6 \%$ & $2.4 \%$ & $7.2 \%$ \\
\hline Bachelor Student & $2.1 \%$ & $3.1 \%$ & $1.4 \%$ & $2.0 \%$ & $3.5 \%$ \\
\hline Librarian & $0.5 \%$ & $3.7 \%$ & $0.5 \%$ & $0.4 \%$ & $1.1 \%$ \\
\hline $\begin{array}{l}\text { Total individual readership } \\
\text { counts }\end{array}$ & 51,453 & 9,892 & 43,599 & 42,967 & 101,276 \\
\hline
\end{tabular}


Table 9. Spearman correlations between WoS citations and Mendeley readership counts (non-zero only) for 2008 articles from Clinical Medicine, Engineering and Technology, Social Science, Physics and Chemistry.

\begin{tabular}{|c|c|c|c|c|}
\hline Main discipline & Sub-discipline & $\begin{array}{l}\text { WoS } \\
\text { citation } \\
\text { median }\end{array}$ & $\begin{array}{l}\text { Mendeley } \\
\text { readership } \\
\text { median }\end{array}$ & Correlation \\
\hline \multirow[t]{8}{*}{ Clinical Medicine } & $\begin{array}{l}\text { Neurology \& } \\
\text { Neurosurgery }\end{array}$ & 10 & 7 & $.585 * *$ \\
\hline & Pharmacology & 9 & 4 & $.536 * *$ \\
\hline & $\begin{array}{l}\text { General \& Internal } \\
\text { Medicine }\end{array}$ & 5 & 4 & $.563 * *$ \\
\hline & Cancer & 12 & 4 & $.604 * *$ \\
\hline & Surgery & 6 & 3 & $.451 * *$ \\
\hline & Immunology & 10 & 5 & $.573 * *$ \\
\hline & Cardiovascular System & 9 & 3 & $.592 * *$ \\
\hline & All & 9 & 4 & $.561 * *$ \\
\hline \multirow{6}{*}{$\begin{array}{l}\text { Engineering and } \\
\text { Technology }\end{array}$} & Mechanical Engineering & 4 & 5 & $.533 * *$ \\
\hline & Computers & 3 & 7 & $.414 * *$ \\
\hline & Electrical Engineering & 4 & 4 & $.442 * *$ \\
\hline & Chemical Engineering & 7 & 5 & $.494 * *$ \\
\hline & Materials Science & 9 & 6 & $.682 * *$ \\
\hline & All & 5 & 5 & $.501 * *$ \\
\hline \multirow[t]{5}{*}{ Social Science } & Economics & 5 & 8 & $.629 * *$ \\
\hline & General Social Science & 3 & 8 & $.552 * *$ \\
\hline & Education & 4 & 9 & $.532 * *$ \\
\hline & LIS & 3 & 10 & $.546 * *$ \\
\hline & All & 4 & 8 & $.561 * *$ \\
\hline \multirow[t]{6}{*}{ Physics } & Applied Physics & 5 & 5 & $.566 * *$ \\
\hline & General Physics & 7 & 5 & $.595 * *$ \\
\hline & $\begin{array}{l}\text { Nuclear \& Particle } \\
\text { Physics }\end{array}$ & 10 & 2 & $.325 * *$ \\
\hline & Optics & 6 & 5 & $.538 * *$ \\
\hline & Solid State Physics & 9 & 7 & $.628 * *$ \\
\hline & All & 7 & 5 & $.548 * *$ \\
\hline \multirow[t]{6}{*}{ Chemistry } & General Chemistry & 15 & 7 & $.648 * *$ \\
\hline & Polymers & 10 & 5 & $.595 * *$ \\
\hline & Physical Chemistry & 10 & 5 & $.527 * *$ \\
\hline & Organic Chemistry & 10 & 4 & $.423 * *$ \\
\hline & Analytical Chemistry & 10 & 4 & $.528 * *$ \\
\hline & All & 11 & 5 & $.554 * *$ \\
\hline
\end{tabular}


Table10. Spearman correlations between Mendeley readership counts and citations based on occupation for Clinical Medicine, Engineering and Technology, Social Science, Physics and

Chemistry articles for all articles regardless of percentage of readership availability.

\begin{tabular}{|c|c|c|c|c|c|c|}
\hline & & $\begin{array}{l}\text { Clinical } \\
\text { Medicine }\end{array}$ & Physics & $\begin{array}{l}\text { Engineering } \\
\text { and } \\
\text { Technology }\end{array}$ & Chemistry & $\begin{array}{l}\text { Social } \\
\text { Sciences }\end{array}$ \\
\hline \multirow[t]{2}{*}{ Professor } & $\begin{array}{l}\text { Spearman's } \\
\text { rho }\end{array}$ & $.404 * *$ & $.439 * *$ & $.482 * *$ & $.435 * *$ & $.485 * *$ \\
\hline & $\mathrm{N}$ & 9,549 & 3,345 & 3,142 & 3,550 & 1,048 \\
\hline \multirow[t]{2}{*}{$\begin{array}{l}\text { Associate } \\
\text { Professor }\end{array}$} & $\begin{array}{l}\text { Spearman's } \\
\text { rho }\end{array}$ & $.292 * *$ & $.337 * *$ & $.288 * *$ & $.379 * *$ & $.345 * *$ \\
\hline & $\mathrm{N}$ & 8,358 & 3,012 & 3,190 & 3,018 & 1,328 \\
\hline \multirow[t]{2}{*}{$\begin{array}{l}\text { Assistant } \\
\text { Professor }\end{array}$} & $\begin{array}{l}\text { Spearman's } \\
\text { rho }\end{array}$ & $.406 * *$ & $.427 * *$ & $.381 * *$ & $.420 * *$ & $.471 * *$ \\
\hline & $\mathrm{N}$ & 11,931 & 3,930 & 4,353 & 3,587 & 2,284 \\
\hline \multirow{2}{*}{$\begin{array}{l}\text { Researcher (at } \\
\text { an Academic } \\
\text { Institution) }\end{array}$} & $\begin{array}{l}\text { Spearman's } \\
\text { rho }\end{array}$ & $.414 * *$ & $.403 * *$ & $.358 * *$ & $.371 * *$ & $.478 * *$ \\
\hline & $\mathrm{N}$ & 17,702 & 6,161 & 5,533 & 5,813 & 1,829 \\
\hline \multirow{2}{*}{$\begin{array}{l}\text { Researcher (at } \\
\text { a non- } \\
\text { Academic } \\
\text { Institution) }\end{array}$} & $\begin{array}{l}\text { Spearman's } \\
\text { rho }\end{array}$ & $.418 * *$ & $.411 * *$ & $.410 * *$ & $.368 * *$ & $.552 * *$ \\
\hline & $\mathrm{N}$ & 9,908 & 3,727 & 4,159 & 5,273 & 725 \\
\hline \multirow[t]{2}{*}{ Post Doc } & $\begin{array}{l}\text { Spearman's } \\
\text { rho }\end{array}$ & $.446 * *$ & $.501 * *$ & $.518 * *$ & $.464 * *$ & $.493 * *$ \\
\hline & $\mathrm{N}$ & 30,274 & 14,014 & 9,210 & 11,626 & 1,420 \\
\hline \multirow[t]{2}{*}{ Ph.D. Student } & $\begin{array}{l}\text { Spearman's } \\
\text { rho }\end{array}$ & $.435^{* *}$ & $.518 * *$ & $.458 * *$ & $.485^{* *}$ & $.523 * *$ \\
\hline & $\mathrm{N}$ & 53,169 & 23,197 & 29,064 & 23,859 & 8,990 \\
\hline \multirow[t]{2}{*}{$\begin{array}{l}\text { Student } \\
\text { (Postgraduate) }\end{array}$} & $\begin{array}{l}\text { Spearman's } \\
\text { rho }\end{array}$ & $.326 * *$ & $.417 * *$ & $.328 * *$ & $.392 * *$ & $.455^{* *}$ \\
\hline & $\mathrm{N}$ & 31,106 & 9,723 & 17,141 & 10,715 & 5,765 \\
\hline \multirow[t]{2}{*}{$\begin{array}{l}\text { Student } \\
\text { (Bachelor) }\end{array}$} & $\begin{array}{l}\text { Spearman's } \\
\text { rho }\end{array}$ & $.245^{* *}$ & $.217 * *$ & $.261 * *$ & $.264 * *$ & $.354 * *$ \\
\hline & $\mathrm{N}$ & 10,990 & 2,000 & 4,045 & 3,147 & 1,510 \\
\hline \multirow[t]{2}{*}{$\begin{array}{l}\text { Other } \\
\text { Professional }\end{array}$} & $\begin{array}{l}\text { Spearman's } \\
\text { rho }\end{array}$ & $.315^{* *}$ & $.219 * *$ & $.122 * *$ & $.171 * *$ & $.294 * *$ \\
\hline & $\mathrm{N}$ & 16,861 & 1,734 & 2,937 & 2,700 & 1,042 \\
\hline \multirow[t]{2}{*}{ Librarian } & $\begin{array}{l}\text { Spearman's } \\
\text { rho }\end{array}$ & $.078 * *$ & -0.003 & -0.05 & -0.033 & $.229 * *$ \\
\hline & $\mathrm{N}$ & 2,808 & 415 & 480 & 370 & 768 \\
\hline
\end{tabular}

**Significant at $\mathrm{p}=0.01$. 
Table 11. Spearman correlations between Mendeley readership counts and citations based on occupation for Clinical Medicine, Engineering and Technology, Social Science, Physics and Chemistry articles for articles with at least $66 \%$ readership availability.

\begin{tabular}{|c|c|c|c|c|c|c|}
\hline Occupation & & $\begin{array}{l}\text { Clinical } \\
\text { Medicine }\end{array}$ & Physics & $\begin{array}{l}\text { Engineering } \\
\text { and } \\
\text { Technology }\end{array}$ & Chemistry & $\begin{array}{l}\text { Social } \\
\text { Sciences } 66 \%\end{array}$ \\
\hline \multirow[t]{2}{*}{ Professor } & Spearman's rho & $.323 * *$ & $.403 * *$ & $.433 * *$ & $.378 * *$ & $.435 * *$ \\
\hline & $\mathrm{N}$ & 7,778 & 3,053 & 2,764 & 3,142 & 826 \\
\hline \multirow[t]{2}{*}{ Associate Professor } & Spearman's rho & $.228 * *$ & $.310 * *$ & $.270 * *$ & $.335 * *$ & $.321 * *$ \\
\hline & $\mathrm{N}$ & 6,399 & 2,720 & 2,832 & 2,647 & 977 \\
\hline \multirow[t]{2}{*}{ Assistant Professor } & Spearman's rho & $.347 * *$ & $.391 * *$ & $.361 * *$ & $.379 * *$ & $.461 * *$ \\
\hline & $\mathrm{N}$ & 8,724 & 3,414 & 3,699 & 3,012 & 1,607 \\
\hline \multirow{2}{*}{$\begin{array}{l}\text { Researcher (at an } \\
\text { Academic } \\
\text { Institution) }\end{array}$} & Spearman's rho & $.328 * *$ & $.371 * *$ & $.329 * *$ & $.324 * *$ & $.419 * *$ \\
\hline & $\mathrm{N}$ & 13,660 & 5,516 & 4,829 & 5,074 & 1,333 \\
\hline \multirow{2}{*}{$\begin{array}{l}\text { Researcher (at a } \\
\text { non-Academic } \\
\text { Institution) }\end{array}$} & Spearman's rho & $.334 * *$ & $.357 * *$ & $.357 * *$ & $.315 * *$ & $.461 * *$ \\
\hline & $\mathrm{N}$ & 7,828 & 3,276 & 3,626 & 4,643 & 532 \\
\hline \multirow[t]{2}{*}{ Post Doc } & Spearman's rho & $.397 * *$ & $.475 * *$ & $.487 * *$ & $.438 * *$ & $.429 * *$ \\
\hline & $\mathrm{N}$ & 22,413 & 12,140 & 7,796 & 9,673 & 1,005 \\
\hline \multirow[t]{2}{*}{ Ph.D. Student } & Spearman's rho & $.405 * *$ & $.504 * *$ & $.446 * *$ & $.467 * *$ & $.499 * *$ \\
\hline & $\mathrm{N}$ & 39,887 & 20,368 & 25,314 & 20,361 & 6,531 \\
\hline \multirow{2}{*}{$\begin{array}{l}\text { Student } \\
\text { (Postgraduate) }\end{array}$} & Spearman's rho & $.262 * *$ & $.388 * *$ & $.310 * *$ & $.358 * *$ & $.396 * *$ \\
\hline & $\mathrm{N}$ & 22,234 & 8,234 & 14,548 & 8,759 & 3,977 \\
\hline \multirow[t]{2}{*}{ Student (Bachelor) } & Spearman's rho & $.173 * *$ & $.195 * *$ & $.232 * *$ & $.237 * *$ & $.298 * *$ \\
\hline & $\mathrm{N}$ & 7,489 & 1,603 & 3,263 & 2,451 & 1,053 \\
\hline \multirow[t]{2}{*}{ Other Professional } & Spearman's rho & $.225 * *$ & $.185 * *$ & $.101 * *$ & $.137 * *$ & $.203 * *$ \\
\hline & $\mathrm{N}$ & 11,683 & 1,397 & 2,313 & 2,068 & 698 \\
\hline \multirow[t]{2}{*}{ Librarian } & Spearman's rho & 0.032 & 0.002 & -0.060 & -0.054 & $.176 * *$ \\
\hline & $\mathrm{N}$ & 1,886 & 356 & 386 & 309 & 567 \\
\hline
\end{tabular}

\footnotetext{
** Significant at $\mathrm{p}=0.01$.
} 
Table 12. Spearman correlations between Mendeley readership counts and citations based on occupation for Clinical Medicine, Engineering and Technology, Social Science, Physics and Chemistry articles for articles with $100 \%$ readership availability.

\begin{tabular}{|c|c|c|c|c|c|c|}
\hline Occupation & & $\begin{array}{l}\text { Clinical } \\
\text { Medicine }\end{array}$ & Physics & $\begin{array}{l}\text { Engineering } \\
\text { and } \\
\text { Technology }\end{array}$ & Chemistry & $\begin{array}{l}\text { Social } \\
\text { Sciences }\end{array}$ \\
\hline \multirow[t]{2}{*}{ Professor } & $\begin{array}{l}\text { Spearman's } \\
\text { rho }\end{array}$ & $.086^{* *}$ & $.094 * *$ & $.149 * *$ & $.095 * *$ & $.130 * *$ \\
\hline & $\mathrm{N}$ & 5,059 & 1,764 & 1,537 & 1,778 & 394 \\
\hline \multirow[t]{2}{*}{ Associate Professor } & $\begin{array}{l}\text { Spearman's } \\
\text { rho }\end{array}$ & $.052 * *$ & 0.024 & 0.012 & $.066 * *$ & -0.008 \\
\hline & $\mathrm{N}$ & 4,289 & 1,729 & 1,798 & 1,637 & 467 \\
\hline \multirow[t]{2}{*}{ Assistant Professor } & $\begin{array}{l}\text { Spearman's } \\
\text { rho }\end{array}$ & $.096 * *$ & $.059 * *$ & $.044 *$ & $.091 * *$ & $.136 * *$ \\
\hline & $\mathrm{N}$ & 5,578 & 1,954 & 2,102 & 1,905 & 650 \\
\hline \multirow[t]{2}{*}{$\begin{array}{l}\text { Researcher (at an Academic } \\
\text { Institution) }\end{array}$} & $\begin{array}{l}\text { Spearman's } \\
\text { rho }\end{array}$ & $.097 * *$ & $.104 * *$ & $.108 * *$ & $.052 * *$ & 0.029 \\
\hline & $\mathrm{N}$ & 7,473 & 2,740 & 2,401 & 2,662 & 464 \\
\hline \multirow[t]{2}{*}{$\begin{array}{l}\text { Researcher (at a non- } \\
\text { Academic Institution) }\end{array}$} & $\begin{array}{l}\text { Spearman's } \\
\text { rho }\end{array}$ & $.109 * *$ & $.058 *$ & $.060 * *$ & $.085^{* *}$ & 0.069 \\
\hline & $\mathrm{N}$ & 4,578 & 1,664 & 1,847 & 2,376 & 202 \\
\hline \multirow[t]{2}{*}{ Post Doc } & $\begin{array}{l}\text { Spearman's } \\
\text { rho }\end{array}$ & $.145^{* *}$ & $.143^{* *}$ & $.144 * *$ & $.161^{* *}$ & $.127 *$ \\
\hline & $\mathrm{N}$ & 10,009 & 5,022 & 3,181 & 3,951 & 316 \\
\hline \multirow[t]{2}{*}{ Ph.D. Student } & $\begin{array}{l}\text { Spearman's } \\
\text { rho }\end{array}$ & $.212 * *$ & $.233 * *$ & $.226 * *$ & $.225^{* *}$ & $.201 * *$ \\
\hline & $\mathrm{N}$ & 19,985 & 9,831 & 12,591 & 9,710 & 2,307 \\
\hline \multirow[t]{2}{*}{ Student (Postgraduate) } & $\begin{array}{l}\text { Spearman's } \\
\text { rho }\end{array}$ & $.077 * *$ & $.061 * *$ & $.095^{* *}$ & $.115^{* *}$ & $.107 * *$ \\
\hline & $\mathrm{N}$ & 11,267 & 3,497 & 6,061 & 3,473 & 1,075 \\
\hline \multirow[t]{2}{*}{ Student (Bachelor) } & $\begin{array}{l}\text { Spearman's } \\
\text { rho }\end{array}$ & 0.001 & -0.056 & 0.047 & 0.063 & $.153 *$ \\
\hline & $\mathrm{N}$ & 3,065 & 547 & 974 & 799 & 276 \\
\hline \multirow[t]{2}{*}{ Other Professional } & $\begin{array}{l}\text { Spearman's } \\
\text { rho }\end{array}$ & $.082 * *$ & -0.016 & 0.019 & -0.003 & -0.079 \\
\hline & $\mathrm{N}$ & 6,036 & 660 & 968 & 923 & 236 \\
\hline \multirow[t]{2}{*}{ Librarian } & $\begin{array}{l}\text { Spearman's } \\
\text { rho }\end{array}$ & 0.004 & -0.005 & -0.036 & -0.097 & -0.079 \\
\hline & $\mathrm{N}$ & 1,046 & 211 & 233 & 179 & 238 \\
\hline
\end{tabular}

**Significant at $\mathrm{p}=0.01$.

\section{References}

Almind, T. C., \& Ingwersen, P. (1997). Informetric analyses on the world wide web: methodological approaches to 'webometrics'. Journal of documentation, 53(4), 404-426.

Armbruster, C. (2008). Access, usage and citation metrics: What function for digital libraries and repositories in research evaluation? Available at SSRN 1088453

Bar-Ilan, J. (2012). JASIST 2001-2010. Bulletin of Association for Information Science and Technology, 24-28.

Barnett, G. A., \& Fink, E. L. (2008). Impact of the internet and scholar age distribution on academic citation age. Journal of the American Society for Information Science and Technology, 59(4), $526-534$. 
Bennett, N. L., Casebeer, L. L., Kristofco, R. E., \& Strasser, S. M. (2004). Physicians' Internet information-seeking behaviors. The Journal of Continuing Education in the Health Professions, 24(1), 31-8.

Bollen, J, \& Sompel, H. V. (2008). Usage impact factor: The effects of sample characteristics on usagebased impact metrics. Journal of the American Society for Information Science and Technology, 59(1), 136-149.

Björneborn, L. (2004). Small-world link structures across an academic Web space: A library and information science approach. Doctoral dissertation, Royal School of Library and Information Science, Copenhagen,Denmark.

Björneborn, L., \& Ingwersen, P. (2004). Toward a basic framework for webometrics. Journal of the American Society for Information Science and Technology, 55(14), 1216-1227.

Bollen, Johan, \& Van De Sompel, H. (2008). Usage Impact Factor: The effects of sample characteristics on usage-based impact metrics. Journal of the American Society for Information Science, 59(1), 13.

Bollen, J., Van De Sompel, H., Hagberg, A., \& Chute, R. (2009). A principal component analysis of 39 scientific impact measures. PLoS ONE, 4(6), e6022.

Bornmann, L. (in press). Is there currently a scientific revolution in scientometrics? Journal of the Association for Information Science and Technology.

Bornmann, L. (2012). Measuring the societal impact of research: research is less and less assessed on scientific impact alone--we should aim to quantify the increasingly important contributions of science to society. EMBO reports, 13(8), 673-6.

Bornmann, L., \& Marx, W. (in press). The wisdom of citing scientists. Journal of the Association for Information Science and Technology.

Brettle, a J., \& Long, A F. (2001). Comparison of bibliographic databases for information on the rehabilitation of people with severe mental illness. Bulletin of the Medical Library Association, 89(4), 353-62.

Catalano, A. (2013). Patterns of graduate students' information seeking behavior: a meta-synthesis of the literature. Journal of Documentation 69, 243-274.

Cohen, J. (1988). Statistical power analysis for the behavioral sciences. (Vol. 2, p. 567). Lawrence Erlbaum Associates.

Costas, R., Zahedi, Z., \& Wouters, P. (2014). Do altmetrics correlate with citations? Extensive comparison of altmetric indicators with citations from a multidisciplinary perspective. Arxiv preprint arXiv: 1401.4321.

Cronin, B. (2013a). Metrics à la mode. Journal of the American Society for Information Science and Technology, 64(6), 1091-1091.

Cronin, B. (2013b). The evolving indicator space (iSpace). Journal of the American Society for Information Science and Technology, 64(8), 1523-1525.

Cronin, B., Snyder, H. W., Rosenbaum, H., Martinson, A., \& Callahan, E. (1998). Invoked on the Web. Journal of the American Society for Information Science, 49(14), 1319-1328.

Egghe, L., \& Rousseau, R. (1990). Introduction to Informetrics: quantitative methods in library, documentation and information science. Amsterdam: Elsevier Science Publishers.

Ellis, D., \& Haugan., M. (1997). Modelling the information seeking patterns of engineers and research scientists in an industrial environment. Journal of documentation, 4(53), 384-403.

Eysenbach, G. (2011). Correction: Can Tweets Predict Citations? Metrics of Social Impact Based on Twitter and Correlation with Traditional Metrics of Scientific Impact. Journal of Medical Internet Research, 13(4), e123.

Fescemyer, K. (2000). Information-seeking behavior of undergraduate geography students. Research Strategies, 17(4), 307-317.

Freund, L., Toms, E. G., \& Waterhouse, J. (2005). Modeling the Information Behaviour of Software Engineers Using a Work - Task Framework. Proceedings of the American Society for Information Science and Technology, 42(1).

Ge, X. (2010). Information-seeking behavior in the digital age: A multidisciplinary study of academic researchers. College \& Research Libraries, 435-455.

Gingras, Y., Larivière, V., Macaluso, B., \& Robitaille, J.-P. (2008). The effects of aging on researchers' publication and citation patterns. PloS ONE, 3(12), e4048. 
Haustein, S., Golov, E., \& Luckanus, K., Reher, S. \& Terliesner, J. (2010). Journal evaluation and science 2.0: Using social bookmarks to analyze reader perception. Book of Abstracts of the 11th International Conference on Science and Technology Indicators (pp. 117-119).

Haustein, S., Larivière, V., Thelwall, M., Amyot, D., \& Peters, I. (submitted). Tweets vs. Mendeley readers: How do these two social media metrics differ? IT - Information Technology.

Haustein, S., Peters, I., Bar-Ilan, J., Priem, J., Shema, H., \& Terliesner, J. (2013). Coverage and adoption of altmetrics sources in the bibliometric community. arXiv, 1-12.

Haustein, S., Peters, I., Thelwall, M., Sugimoto, C.R., Larivière, V. (in press) Tweeting biomedicine: an analysis of tweets and citations in the biomedical literature. Journal of the Association for Information Science and Technology.

Haustein, S., \& Siebenlist, T. (2011). Applying social bookmarking data to evaluate journal usage. Journal of Informetrics, 5(3), 446-457.

HEFCE. (2011). Research Excellence Framework (Vol. 2011). Higher Education Funding Council for England.

Hemminger, B. M., Lu, D., Vaughan, K. T. L., \& Adams, S. J. (2007). Information seeking behavior of academic scientists. Journal of the American Society for Information Science and Technology, 58(14), 2205-2225.

Hertzum, M., \& Pejtersen, A. M. (2000). The information-seeking practices of engineers: searching for documents as well as for people. Information Processing \& Management, 36(5), 761-778.

Jamali, H. R., \& Nicholas, D. (2006). Communication and information-seeking behavior of PhD students in physicists and astronomy. Proceedings of the American Society for Information Science and Technology, 43(1), 1-18.

Jones, T. H., Donovan, C., \& Hanney, S. (2012). Tracing the wider impacts of biomedical research: a literature search to develop a novel citation categorisation technique. Scientometrics, 1-10.

Korobili, S., Malliari, A., \& Zapounidou, S. (2011). Factors that Influence Information-Seeking Behavior: The Case of Greek Graduate Students. The Journal of Academic Librarianship, 37(2), 155-165.

Kostoff, R. (1998). The use and misuse of citation analysis in research evaluation. Scientometrics, $1(1), 27-43$.

Kurtz, M., \& Bollen, J. (2010). Usage bibliometrics. Annual Review of Information Science and Technology, 44(1-64).

Kwasitsu, L. (2003). Information-seeking behavior of design , process, and manufacturing engineers. Library \& Information Science Research, 25(4), 459-476.

Larivière, V., Sugimoto, C. R., \& Bergeron, P. (2013). In their own image? a comparison of doctoral students' and faculty members' referencing behavior. Journal of the American Society for Information Science and Technology, 64(5), 1045-1054.

Leckie, G., Pettigrew, K., \& Sylvain, C. (1996). Modeling the information seeking of professionals: a general model derived from research on engineers, health care professionals, and lawyers. The Library Quarterly.

Li, \& Thelwall, M. (2012). F1000 , Mendeley and Traditional Bibliometric Indicators. 17th International Conference on Science and Technology Indicators (Vol. 3, pp. 1-11).

Li, X., Thelwall, M., \& Giustini, D. (2012). Validating online reference managers for scholarly impact measurement. Scientometrics, 91(2), 461-471.

MacRoberts, M. H., \& MacRoberts, B. R. (1989). Problems of citation analysis: A critical review. Journal of the American Society for Information Science, 40(5), 342-349.

Martin, B. R. (1996). The use of multiple indicators in the assessment of basic research. Scientometrics, 36(3), 343-362.

Mas Bleda, A., Thelwall, M., Kousha, K. \& Aguillo, I. (2013). European highly cited scientists' presence in the social web. In J. Gorraiz, E. Schiebel, C. Gumpenberger, M. Hörlesberger and H. Moed (Eds.), 14th International Society of Scientometrics and Informetrics Conference (ISSI 2013), (pp. 98-109). Vienna: Austria.

McAlister, F. A., Graham, I., Karr, G. W., \& Laupacis, A. (1999). Evidence-based medicine and the practicing clinician. Journal of General Internal Medicine, 14(4), 236-242. 
Mohammadi, E., \& Thelwall, M. (in press). Mendeley readership altmetrics for the social sciences and humanities: Research evaluation and knowledge flows. Journal of the American Society for Information Science and Technology.

Mohammadi, E., \& Thelwall, M. ( 2013). Assessing non-standard article impact using F1000 labels. Scientometrics, 97(2), 383-395.

Nederhof. (2006). Bibliometric monitoring of research performance in the Social Sciences and the Humanities: A Review. Scientometrics, 66(1), 81-100.

Nicholas, D., Huntington, P., Dobrowolski, T., Rowlands, I., Jamali M., H. R., \& Polydoratou, P. (2005). Revisiting "obsolescence" and journal article "decay" through usage data: an analysis of digital journal use by year of publication. Information Processing \& Management, 41(6), 14411461.

Niu, X., \& Hemminger, B. M. (2012). A study of factors that affect the information-seeking behavior of academic scientists. Journal of the American Society for Information Science and Technology, 63(2), 336-353.

Pancheshnikov, Y. (2007). A Comparison of Literature Citations in Faculty Publications and Student Theses as Indicators of Collection Use and a Background for Collection Management at a University Library. The Journal of Academic Librarianship, 33(6), 674-683.

Piwowar, H. (2013). Altmetrics: Value all research products. Nature, 493(7431), 159-159.

Price, D., \& Gürsey, S. (1975). Studies in Scientometrics I Transience and Continuance in Scientific Authorship. Ciência da Informação.

Priem, J. (2013). Scholarship: Beyond the paper. Nature, 495(7442), 437-440. doi:10.1038/495437a

Priem, J., Piwowar, H. A., \& Hemminger, B. M. (2012). Altmetrics in the wild: Using social media to explore scholarly impact. Arxiv preprint arXiv:1203.4745.

Priem, Taraborelli, D., Groth, P., \& Neylon, C. (2011). altmetrics: a manifesto. Retrieved from http://altmetrics.org/manifesto

Rousseau, R., \& Ye, F. (2013). A multi-metric approach for research evaluations. Chinese Science Bulletin, 1-7.

Rowlands, I., \& Nicholas, D. (2007). The missing link: journal usage metrics. Aslib Proceedings, 59(3), 222-228. Schilling, L. M., Steiner, J. F., Lundahl, K., \& Anderson, R. J. (2005). Residents' patient-specific clinical questions: opportunities for evidence-based learning. Academic medicine: journal of the Association of American Medical Colleges, 80(1), 51-6.

Schloegl, C., \& Stock, W. G. (2004). Impact and relevance of LIS journals: A scientometric analysis of international and German-language LIS journals - Citation analysis versus reader survey. Journal of the American Society for Information Science and Technology, 55(13), 1155-1168.

Shema, H., Bar-Ilan, J., \& Thelwall, M. (in press). Do blog citations correlate with a higher number of future citations? Research blogs as a potential source for alternative metrics. Journal of the American Society for Information Science and Technology.

Tague-Sutcliffe, J. (1992). An introduction to informetrics. Information Processing \& Management, 28(1), 1-3.

Taylor, P., Aurisicchio, M., Bracewell, R., \& Wallace, K. (2010). Journal of Engineering Design Understanding how the information requests of aerospace engineering designers influence information- seeking behaviour engineering designers influence information-seeking behaviour. Journal of Engineering Design, 21(6), 707-730.

Tenopir, C., \& King, D. W. (2000). Towards Electronic Journals: Realities for Scientists, Librarians, and Publishers. Washington, D. C.: Special Libraries Association.

Tenopir, C., King, D. W., Clarke, M. T., Na, K., \& Zhou, X. (2007). Journal reading patterns and preferences of pediatricians. Journal of the Medical Library Association: JMLA, 95(1), 56-63.

Tenopir, C., King, D. W., Spencer, J., \& Wu, L. (2009). Variations in article seeking and reading patterns of academics: What makes a difference? Library \& Information Science Research, 31(3), 139-148.

Thelwall, M. (2012). Journal impact evaluation: a webometric perspective. Scientometrics, 92(2), 429-441.

Thelwall, M., Haustein, S., Larivière, V., \& Sugimoto, C. R. (2013). Do altmetrics work? Twitter and ten other social web services. PLOS ONE, 8(5), e64841. 
Thelwall, M., \& Kousha, K. (in press). Academia.edu: Social network or academic network? Journal of the Association for Information Science and Technology.

Waltman, L., \& Costas, R. (in press). F1000 recommendations as a potential new data source for research evaluation: A comparison with citations, Journal of the American Society for Information Science and Technology

Whitmire, E. (2002). Disciplinary differences and undergraduates' information-seeking behavior. Journal of the American Society for Information Science and Technology, 53(8), 631-638.

Zahedi, Z., Costas, R., \& Wouters, P. (2013). How well developed are Altmetrics? Cross-disciplinary analysis of the presence of "alternative metrics" in scientific publications. 14th International Society of Scientometrics and Informetrics Conference (ISSI) (pp. 876-884). Vienna: Austrian Institute of Technology. 